\title{
Front Matter: Volume 7897
}

, "Front Matter: Volume 7897," Proc. SPIE 7897, Optical Interactions with Tissue and Cells XXII, 789701 (8 April 2011); doi: 10.1117/12.890765

SPIE. Event: SPIE BiOS, 2011, San Francisco, California, United States 


\title{
PROGRESS IN BIOMEDICAL OPTICS AND IMAGING
}

Vol. 12, No. 15

\section{Optical Interactions with Tissue and Cells XXII}

\author{
E. Duco Jansen \\ Robert J. Thomas \\ Editors
}

24-26 January 2011

San Francisco, California, United States

Sponsored and Published by

SPIE

Volume 7897

Proceedings of SPIE, 1605-7422, v. 7897

SPIE is an international society advancing an interdisciplinary approach to the science and application of light. 
The papers included in this volume were part of the technical conference cited on the cover and title page. Papers were selected and subject to review by the editors and conference program committee. Some conference presentations may not be available for publication. The papers published in these proceedings reflect the work and thoughts of the authors and are published herein as submitted. The publisher is not responsible for the validity of the information or for any outcomes resulting from reliance thereon.

Please use the following format to cite material from this book:

Author(s), "Title of Paper," in Optical Interactions with Tissue and Cells XXII, edited by E. Duco Jansen, Robert J. Thomas, Proceedings of SPIE Vol. 7897 (SPIE, Bellingham, WA, 2011) Article CID Number.

ISSN 1605-7422

ISBN 9780819484345

Published by

SPIE

P.O. Box 10, Bellingham, Washington 98227-0010 USA

Telephone +1 3606763290 (Pacific Time) · Fax +1 3606471445

SPIE.org

Copyright (C) 2011, Society of Photo-Optical Instrumentation Engineers.

Copying of material in this book for internal or personal use, or for the internal or personal use of specific clients, beyond the fair use provisions granted by the U.S. Copyright Law is authorized by SPIE subject to payment of copying fees. The Transactional Reporting Service base fee for this volume is $\$ 18.00$ per article (or portion thereof), which should be paid directly to the Copyright Clearance Center (CCC), 222 Rosewood Drive, Danvers, MA 01923. Payment may also be made electronically through CCC Online at copyright.com. Other copying for republication, resale, advertising or promotion, or any form of systematic or multiple reproduction of any material in this book is prohibited except with permission in writing from the publisher. The CCC fee code is 1605 $7422 / 11 / \$ 18.00$.

Printed in the United States of America.

Publication of record for individual papers is online in the SPIE Digital Library.

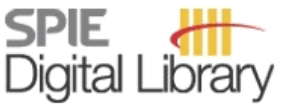

SPIEDigitallibrary.org

Paper Numbering: Proceedings of SPIE follow an e-First publication model, with papers published first online and then in print and on CD-ROM. Papers are published as they are submitted and meet publication criteria. A unique, consistent, permanent citation identifier (CID) number is assigned to each article at the time of the first publication. Utilization of CIDs allows articles to be fully citable as soon they are published online, and connects the same identifier to all online, print, and electronic versions of the publication. SPIE uses a six-digit CID article numbering system in which:

- The first four digits correspond to the SPIE volume number.

- The last two digits indicate publication order within the volume using a Base 36 numbering system employing both numerals and letters. These two-number sets start with $00,01,02,03,04$, $05,06,07,08,09,0 A, 0 B \ldots$. 0Z, followed by 10-1Z, 20-2Z, etc.

The CID number appears on each page of the manuscript. The complete citation is used on the first page, and an abbreviated version on subsequent pages. Numbers in the index correspond to the last two digits of the six-digit CID number. 


\section{Contents}

ix Conference Committee

\section{PHOTO-MECHANICAL INTERACTIONS I}

789704 Mechanisms of femtosecond laser cell surgery in the low-density plasma regime [7897-03] K. Kuetemeyer, R. Rezgui, H. Lubatschowski, A. Heisterkamp, Laser Zentrum Hannover e.V. (Germany)

789706 Ultrafast laser assisted microinjection enables distinct spatial localization pattern in cells and retina [7897-05]

L. Gu, S. Shivalingaiah, S. K. Mohanty, The Univ. of Texas at Arlington (United States)

789707 Endovenous laser ablation with TM-fiber laser [7897-06]

M. F. Somunyudan, N. Topaloglu, Bogazici Univ. (Turkey); M. U. Ergenoglu, Yeditepe Univ. Hospital (Turkey); M. Gulsoy, Bogazici Univ. (Turkey)

\section{PHOTO-MECHANICAL INTERACTIONS II}

789708 Assessing mechanical properties with intravascular or endoscopic optical coherence tomography [7897-07]

G. Lamouche, National Research Council Canada (Canada); H. Azarnoush, National Research Council Canada (Canada) and McGill Univ. (Canada); S. Vergnole, V. Pazos, C.-É. Bisaillon, P. Debergue, National Research Council Canada (Canada); B. Boulet, McGill Univ. (Canada); R. Diraddo, National Research Council Canada (Canada)

7897 OA Non-invasive optical modulation of local vascular permeability [7897-09]

M. Choi, C. Choi, KAIST (Korea, Republic of)

7897 OB Laser-induced detachment and re-orientation of cells [7897-10]

L. Gu, N. Ingle, S. K. Mohanty, The Univ. of Texas at Arlington (United States)

\section{TERAHERTZ FREQUENCY INTERACTIONS}

7897 OC Terahertz pulsed imaging in vivo (Invited Paper) [7897-11]

E. Pickwell-MacPherson, Hong Kong Univ. of Science and Technology (Hong Kong, China)

7897 OD THz techniques for human skin measurement [7897-12]

Y. Guan, Nagoya Univ. (Japan); K. Mizukoshi, POLA Chemical Industries, Inc. (Japan);

K. Suizu, Nagoya Univ. (Japan); K. Kawase, Nagoya Univ. (Japan) and RIKEN (Japan) 
7897 OE Gene expression profile of Jurkat cells exposed to high power terahertz radiation [7897-13] J. E. Grundt, Air Force Research Lab. (United States); C. C. Roth, General Dynamics Advanced Information Systems, Inc. (United States); B. D. Rivest, M. L. Doroski, J. Payne, B. L. Ibey, Air Force Research Lab. (United States); G. J. Wilmink, Air Force Research Lab. (United States) and National Academy of Sciences (United States)

7897 OF Accelerating thermal deposition modeling at terahertz frequencies using GPUs [7897-14] M. Doroski, M. Knight, J. Payne, J. E. Grundt, B. L. Ibey, R. Thomas, W. P. Roach, G. J. Wilmink, Air Force Research Lab. (United States)

\section{PHOTO-THERMAL INTERACTIONS I}

$7897 \mathrm{OH} \quad$ Bioheat model evaluations of laser effects on tissues: role of water evaporation and diffusion [7897-16]

D. Nagulapally, R. P. Joshi, Old Dominion Univ. (United States); R. J. Thomas, Air Force Research Lab. (United States)

7897 Ol Effects of He-Ne laser irradiation on red blood cells in vitro [7897-17] V. H. Ghadage, G. R. Kulkarni, Univ. of Pune (India)

$78970 \mathrm{~J} \mathrm{Temperature} \mathrm{increase} \mathrm{of} \mathrm{ex} \mathrm{vivo} \mathrm{corneas} \mathrm{from} \mathrm{multiple} \mathrm{2.01-micron} \mathrm{incident} \mathrm{laser} \mathrm{pulses}$ [7897-18]

E. Kelly, T. Johnson, Colorado State Univ. (United States)

7897 OK Characterizing temperature-dependent photo-oxidation to explain the abrupt transition from thermal to non-thermal laser damage mechanisms at $413 \mathrm{~nm}$ [7897-19] M. L. Denton, C. D. Clark III, G. D. Noojin, TASC, Inc. (United States); L. E. Estlack, Conceptual MindWorks (United States); A. C. Schenk, C. W. Burney, B. A. Rockwell, R. J. Thomas, Air Force Research Lab. (United States)

\section{SPECTROSCOPY AND TRANSPORT THEORY I}

7897 OP Detection of familial adenomatous polyposis with polarized spectroscopic imaging and oral vascular density [7897-24]

A. Basiri, The Catholic Univ. of America (United States); D. L. Edelstein, F. M. Giardiello, The Johns Hopkins Univ. (United States); J. C. Ramella-Roman, The Catholic Univ. of America (United States) and The Johns Hopkins Univ. (United States)

$78970 Q \quad$ Determining the optical properties in a fibrous turbid medium [7897-25]

A. Shuaib, G. Yao, Univ. of Missouri-Columbia (United States)

7897 OR Detection of cancer cells in prostate tissue with time-resolved fluorescence spectroscopy [7897-26]

C. E. Gerich, J. Opitz, Fraunhofer-Institut für Zerstörungsfreie Prüfverfahren (Germany); M. Toma, M. Sergon, S. Füssel, Universitätsklinikum Carl Gustav Carus Dresden (Germany); R. Nanke, J. Fehre, Siemens AG (Germany); M. Wirth, G. Baretton, Universitätsklinikum Carl Gustav Carus Dresden (Germany); J. Schreiber, Fraunhofer-Institut für Zerstörungsfreie Prüfverfahren (Germany) 
7897 OS Behavior of optical properties of coagulated blood sample at $633 \mathrm{~nm}$ wavelength [7897-27] B. Morales Cruzado, S. Vázquez y Montiel, J. A. Delgado Atencio, Instituto Nacional de Astrofísica, Óptica y Electrónica (Mexico)

\section{SPECTROSCOPY AND TRANSPORT THEORY II}

7897 OT Vibrational spectroscopy characterization of low level laser therapy on mammary culture cells: a micro-FTIR study [7897-28]

T. D. Magrini, N. Villa dos Santos, M. Pecora Milazzotto, G. Cerchiaro, H. da Silva Martinho, Univ. Federal do ABC (Brazil)

7897 OU Detection of pre-charring optical behavior at a laser catheter-tip in blood: ex vivo and in vivo study [7897-29]

M. Takahashi, A. Ito, T. Kajihara, T. Arai, Keio Univ. (Japan)

7897 OV Three-dimensional angular domain optical projection tomography [7897-30]

E. Ng, Lawson Health Research Institute (Canada) and The Univ. of Western Ontario (Canada); F. Vasefi, Lawson Health Research Institute (Canada), The Univ. of Western Ontario (Canada), and Simon Fraser Univ. (Canada); M. Roumeliotis, Lawson Health Research Institute (Canada) and The Univ. of Western Ontario (Canada); B. Kaminska, Simon Fraser Univ. (Canada); J. J. L. Carson, Lawson Health Research Institute (Canada) and The Univ. of Western Ontario (Canada)

7897 OW Angular-domain imaging of fluorescence sources within tissue phantoms [7897-31] R. L. K. Cheng, P. Tsui, G. H. Chapman, R. Qarehbaghi, N. Pfeiffer, Simon Fraser Univ. (Canada)

7897 OX Optical technique for the investigation of light transport within irradiated tissues [7897-71] R. Ankri, H. Taitelbaum, D. Fixler, Bar-llan Univ. (Israel)

\section{PHOTO-THERMAL INTERACTIONS II}

$78970 Z$ Photothermal therapy of cancer cells using magnetic carbon nanoparticles [7897-33] V. Vardarajan, L. GU, A. Kanneganti, S. K. Mohanty, A. R. Koymen, The Univ. of Texas at Arlington (United States)

789710 Photothermal therapy of acute leukemia cells in the near-infrared region using gold nanorods CD-33 conjugates [7897-34]

A. Liopo, A. Conjusteau, TomoWave Labs., Inc. (United States); M. Konopleva, M. Andreeff, The Univ. of Texas M.D. Anderson Cancer Ctr. (United States); A. Oraevsky, TomoWave Labs., Inc. (United States)

789711 Skin damage thresholds with continuous wave laser exposures at the infrared wavelength of $1319 \mathrm{~nm}$ [7897-35]

J. W. Oliver, Air Force Research Lab. (United States); C. A. Harbert, G. D. Noojin, I. D. Noojin, K. J. Schuster, A. D. Shingledecker, D. J. Stolarski, TASC, Inc. (United States); S. S. Kumru, Air

Force Research Lab. (United States) 
789712 Metal nanoparticles amplify photodynamic effect on skin cells in vitro [7897-37]

B. Baver, Univ. of Gothenburg (Sweden); S. Chen, M. Käll, L. Gunnarsson, Chalmers Univ. of Technology (Sweden); M. B. Ericson, Univ. of Gothenburg (Sweden)

789713 Laser injury and in vivo multimodal imaging using a mouse model [7897-38]

G. M. Pocock, Air Force Research Lab. (United States); A. Boretsky, P. Gupta, The Univ. of Texas Medical Branch at Galveston (United States); J. W. Oliver, Air Force Research Lab. (United States); M. Motamedi, The Univ. of Texas Medical Branch at Galveston (United States)

789714 Optical control of urinary bladder contraction using femtosecond-pulsed laser [7897-39] J. Yoon, M. Choi, C. Choi, KAIST (Korea, Republic of)

789716 No effect of femtosecond laser pulses on DNA, protein, M13, or E. coli [7897-41] J. C. Wigle, E. A. Holwitt, Air Force Research Lab. (United States); G. D. Noojin, TASC, Inc. (United States); L. E. Estlack, Conceptual MindWorks, Inc. (United States); K. E. Sheldon, B. A. Rockwell, Air Force Research Lab. (United States)

789717 Correlating computational docking predictions with Raman spectroscopy for $\beta$-lactoglobulin-porphyrin complexes [7897-42]

J. Parker, L. Brancaleon, The Univ. of Texas at San Antonio (United States)

IMAGING I

$789718 \quad$ Rotating wall vessel system designed for fluorescent imaging [7897-43]

T. J. Tayag, Texas Christian Univ. (United States); S. D. Dimitrijevich, Univ. of North Texas Health Science Ctr. at Fort Worth (United States); L. C. Del Gallego, P. Kumar, Texas Christian Univ. (United States)

789719 Characterization of tissue scaffolds using optics and ultrasound [7897-44]

N. T. Huynh, The Univ. of Nottingham (United Kingdom); N. G. Parker, Univ. of Leeds (United Kingdom); D. He, H. Ruan, B. R. Hayes-Gill, M. L. Mather, J. A. Crowe, F. R. A. J. Rose, The Univ. of Nottingham (United Kingdom); M. J. W. Povey, Univ. of Leeds (United Kingdom); S. P. Morgan, The Univ. of Nottingham (United Kingdom)

7897 1B Validation of artificial skin equivalents as in vitro testing systems [7897-46] R. Schmitt, RWTH Aachen Univ. (Germany) and Fraunhofer Institute for Production Technology (Germany); U. Marx, Fraunhofer Institute for Production Technology (Germany); H. Walles, L. Schober, Fraunhofer Institute for Interfacial Engineering and Biotechnology (Germany)

IMAGING II

7897 ID Electrospun fiber alignment using the radon transform [7897-48]

N. J. Schaub, Michigan Technological Univ. (United States); R. J. Gilbert, Michigan Technological Univ. (United States) and Rensselaer Polytechnic Institute (United States); S. J. Kirkpatrick, Michigan Technological Univ. (United States) 
7897 IG Optical methods for diagnostics and feedback control in laser-induced regeneration of spine disc and joint cartilages (Invited Paper) [7897-51]

E. Sobol, A. Sviridov, A. Omeltchenko, O. Baum, Institute on Laser and Information Technologies (Russian Federation) and Arcuo Medical Inc. (United States); A. Baskov, I. Borchshenko, Ctr. for Vertebrology and Orthopedics (Russian Federation) and Arcuo Medical Inc. (United States); V. Golubev, Ctr. for Vertebrology and Orthopedics (Russian Federation); V. Baskov, Ctr. for Vertebrology and Orthopedics (Russian Federation) and Arcuo Medical Inc. (United States)

$7897 \mathrm{lJ}$ Stretching of red blood cells by optical tweezers quantified by digital holographic microscopy [7897-54]

N. Cardenas, The Univ. of Texas at Arlington (United States); L. YU, Nanoscope Technologies LLC (United States); S. K. Mohanty, The Univ. of Texas at Arlington (United States)

POSTER SESSION

$7897 \mathrm{lK} \quad$ Laser ultrasound characterization of normal and decayed teeth by measuring elastic properties of surface layers [7897-55]

Y. H. El-Sharkawy, A. F. ElSherif, Egyptian Armed Forces (Egypt)

7897 IL VEGF-C as a survival factor for retinal pigment epithelial cells from photothermal stress [7897-56]

B. J. Lavey, K. E. Sheldon, Air Force Research Lab. (United States); L. E. Estlack, Conceptual MindWorks, Inc. (United States); K. J. Schuster, TASC, Inc. (United States); M. D. Barnhart, U.S. Air Force Academy (United States); B. A. Rockwell, Air Force Research Lab. (United States)

7897 1M Analysis on unevenness of skin color using the melanin and hemoglobin components separated by independent component analysis of skin color image [7897-57]

N. Ojima, KAO Corp. (Japan); I. Fujiwara, Chiba Univ. (Japan); Y. Inove, KAO Corp. (Japan); N. Tsumura, T. Nakaguchi, Chiba Univ. (Japan); K. Iwata, KAO Corp. (Japan)

7897 iN Monte Carlo simulation for light propagation in 3D tooth model [7897-58]

Y. Fu, Sharp Labs. of America, Inc. (United States); S. L. Jacques, Oregon Health \& Science Univ. (United States)

7897 1Q Angular-domain spectroscopic imaging of turbid media: derivative analysis [7897-61] F. Vasefi, Lawson Health Research Institute (Canada), The Univ. of Western Ontario (Canada), and Simon Fraser Univ. (Canada); M. Najiminaini, Lawson Health Research Institute (Canada) and Simon Fraser Univ. (Canada); E. Ng, Lawson Health Research Institute (Canada) and The Univ. of Western Ontario (Canada); A. Chamson-Reig, Lawson Health Research Institute (Canada); B. Kaminska, Simon Fraser Univ. (Canada); J. J. L. Carson, Lawson Health Research Institute (Canada) and The Univ. of Western Ontario (Canada)

7897 is FDTD multi-GPU implementation of Maxwell's equations in dispersive media [7897-63] M. R. Zunoubi, SUNY, New Paltz (United States); J. Payne, M. Knight, Air Force Research Lab. (United States) 
7897 1T Human skin auto-fluorescence decay as a function of irradiance and skin type [7897-64] M. P. Debreczeny, MPD Consulting (United States); R. Bates, R. M. Fitch, K. P. Galen, J. Ge, R. B. Dorshow, Covidien Pharmaceuticals (United States)

7897 IV Traumatic brain injury caused by laser-induced shock wave in rats: a novel laboratory model for studying blast-induced traumatic brain injury [7897-66]

B. Hatano, Y. Matsumoto, Military Medicine Research Unit, Japan Self-Defense Force (Japan) and Japan Self-Defense Force Central Hospital (Japan); N. Otani, D. Saitoh, S. Tokuno, Y. Satoh, H. Nawashiro, National Defense Medical College (Japan); Y. Matsushita, Military Medicine Research Unit, Japan Self-Defense Force (Japan); S. Sato, National Defense Medical College (Japan)

7897 IW Error analysis of tissue optical properties determined by double-integrating sphere system and inverse Monte Carlo method [7897-67]

T. Terada, T. Nanjo, N. Honda, K. Ishii, Osaka Univ. (Japan); K. Awazu, Osaka Univ. (Japan), Japan Science and Technology Agency (Japan), Univ. of Fukui (Japan), and Kyoto Univ. (Japan)

$78971 \mathrm{X}$ Optical imaging through non-transparent small aquatic creatures with angular-domain imaging [7897-68]

R. L. K. Cheng, P. B. L. Tsui, G. Chiang, G. H. Chapman, Simon Fraser Univ. (Canada)

7897 IY Photo-induced unfolding of tubulin dimers bound to meso-tetrakis (sulfonatophenyl) porphyrin [7897-69]

B. McMicken, L. Brancaleon, The Univ. of Texas at San Antonio (United States)

Author Index 


\title{
Conference Committee
}

\author{
Symposium Chairs \\ James G. Fujimoto, Massachusetts Institute of Technology (United \\ States) \\ R. Rox Anderson, Wellman Center for Photomedicine, Massachusetts \\ General Hospital, Harvard School of Medicine (United States)
}

Program Track Chairs

Steven L. Jacques, Oregon Health \& Science University (United States)

William P. Roach, U.S. Air Force (United States)

\section{Conference Chairs}

E. Duco Jansen, Vanderbilt University (United States)

Robert J. Thomas, Air Force Research Laboratory (United States)

Program Committee

Stephen A. Boppart, University of Illinois at Urbana-Champaign (United States)

Irene Georgakoudi, Tufts University (United States)

Randolph D. Glickman, The University of Texas Health Science Center at San Antonio (United States)

Miya Ishihara, National Defense Medical College (Japan)

Sean J. Kirkpatrick, Michigan Technological University (United States)

Duncan J. Maitland, The Texas A\&M University System (United States)

Stephen P. Morgan, The University of Nottingham (United Kingdom)

Jessica C. Ramella-Roman, The Catholic University of America (United States)

Marissa N. Rylander, Virginia Polytechnic Institute and State University (United States)

Alfred Vogel, Universität zu Lübeck (Germany)

Lihong V. Wang, Washington University in St. Lovis (United States)

Gerald J. Wilmink, Air Force Research Laboratory (United States)

Ying Yang, Keele University (United Kingdom)

Session Chairs

Keynote Session

E. Duco Jansen, Vanderbilt University (United States) 
Photo-Mechanical Interactions I

E. Duco Jansen, Vanderbilt University (United States)

Photo-Mechanical Interactions II

Duncan J. Maitland, The Texas A\&M University System (United States)

Terahertz Frequency Interactions

Gerald J. Wilmink, Air Force Research Laboratory (United States)

Photo-Thermal Interactions I

Robert J. Thomas, Air Force Research Laboratory (United States)

Spectroscopy and Transport Theory I

Jessica C. Ramella-Roman, The Catholic University of America (United States)

Spectroscopy and Transport Theory II

Robert J. Thomas, Air Force Research Laboratory (United States)

Photo-Thermal Interactions II

William P. Roach, U.S. Air Force (United States)

Photo-Chemical Interactions

Randolph D. Glickman, The University of Texas Health Science Center at San Antonio (United States)

Imaging I

Sean J. Kirkpatrick, Michigan Technological University (United States)

Imaging II

Stephen P. Morgan, The University of Nottingham (United Kingdom)

Effects of Light on Cells and Tissues

Miya Ishihara, National Defense Medical College (Japan) 